\title{
Effects of grasshopper control programs on rangeland breeding bird populations
}

\author{
T. LUKE GEORGE, LOWELL C. MCEWEN, AND BRETT E. PETERSEN
}

\begin{abstract}
Authors are assistant professor, Department of Wildife, Humboldt State University, Arcata, Calif. research scientist and research associate, Deparment of Fishery and Wildlife Biology; Colorado State University, Fort Collins. At the time the research was conducted, the senior author was research associate, Department of Fishen and Wildlife Biology, Colorado State Uniwersity, Font Collins.
\end{abstract}

\begin{abstract}
We investigated the effects of grasshopper control methods on breeding bird populations in western rangelands. We estimated bird densities on 13 treated and 11 untreated sites before and after grasshopper control operations. Four different treatments were used in these applications: malathion, sevin-4-oil, carbaryl bait and Nosema locustae bait. There were few differences among the 4 treatments in their effects on bird community parameters (total bird density, and species richness, diversity, or evenness). Bird community parameters did not differ between spray and bait applications but sample sizes were small for bait treatments. When data from all treatments were combined for analysis, there was no difference in any of the bird community parameters between pre- and post-treatment samples. Densities of western meadowlarks (Sturnella neglecta), however, were significantly lower on treated than untreated sites 10 and 21 days after treatment. We found no relationship between changes in bird numbers 21 days post-treatment and either the size of the area treated or the date of treatment (i.e., early or late in nesting season). Malathion is an acetylcholinesterase (AChE) inhibitor, but brain AChE levels in birds collected on sites treated with malathion showed no significant inhibition. These results suggest that grasshopper integrated pest management treatments generally have little effect on breeding bird communities but some insectivorous bird species may decline on rangeland treated with broadspectrum insecticides because of reduction in food base. Pesticide applications that have adverse impacts on birds and other nontarget wildlife that prey on grasshoppers may be counterproductive to longterm integrated pest management goals.
\end{abstract}

Key Words: acetylcholinesterase, birds, carbaryl, indirect effects, malathion, Nosema locustae, pesticide

Large areas of rangeland in the wevtern United States are treated with insecticides each year to control grasshopper outbreaks.

We thank J. Adams, S. Allen. L. Amold. D. Chrrstensen, E. Cromie, S. Kittrell, M. Stratmen. A. Fowler, F. Howe. C. Miller, S. Miller, C. Nelson, D. Periman, R. Sherman, C. Sills, K. Ward, and A. Wurner for help in collecting data. This research was supported by a cooperative agreement between USDA-APHIS and Colorado State University, Lowell McEwen Prncipal Investigator.

Manuscript accepted 6 Nov. 1994.
Many of these control programs are conducted by the USDAAPHIS (U.S. Department of Agriculture-Animal Plant Health Inspection Service) in cooperation with other federal agencies, state departments of agriculture, and local land owners. The large extent of some treated blocks (often $>40,000$ ha) and application of pesticides to environmentally-sensitive areas have caused concern over the potential impacts on nontarget vertebrates (USDAAPHIS 1987).

Under current regulations liquid formulations of malathion. carbaryl, and acephate and bait formulations of carbaryl, and Nosema locustae (a biological control agent) may be used to control grasshoppers on rangeland. The low insecticide application rates that are used on rangeland generally result in low to moderate insecticide concentrations in insect prey that may be ingested by birds (McEwen et al. 1972). However, pesticide applications during the nesting season may indirectly affect bird populations by reducing arthropod prey which are an important part of the diet of young and adult birds (Grue et al. 1983, McEwen 1987, Johnson and Boyce 1990). The objectives of this study were to examine the direct and indirect effects of grasshopper control programs on breeding bird populations on rangelands in the western United States.

\section{Study Area and Methods}

\section{Bird Surveys}

We conducted bird surveys on 13 areas treated for grasshoppers and 11 untreated sites in 5 western states from 1987-1990 (Table 1). In 2 cases, we used a single untreated area as a control for 2 trcatments. We survcyed all grasshopper treatments conducted by the USDA-APHIS within the grasshopper integrated pest management demonstration area in McKenzie County, N.D. We also conducted surveys on 6 grasshopper treatments in Utah, Colorado, Wyoming, and Idaho. Treatments were selected and applied following USDA-APHIS regulations (USDA 1987). Because treated areas were selected by USDA-APHIS personnel for range grasshopper control, the treatments were not randomly assigned and therefore represent quasiexperiments (Cook and Campbell 1979). However, given the difficulty of conducting large-scale experiments and the possible scale dependence of treatment effects (Carpenter 1990), we feel an analysis of these 
Table 1. Location and description of treatments.

\begin{tabular}{|c|c|c|c|c|}
\hline Year & County. State & Pesticide & $\begin{array}{r}\text { Area } \\
\text { (ha) }\end{array}$ & $\begin{array}{c}\text { Date of } \\
\text { Application } 1\end{array}$ \\
\hline 1987 & Moffat, Colo. & carbaryl butt ${ }^{2}$ & 1,300 & I July \\
\hline 1987 & Uintah, Utah & sevin-4-oil ${ }^{3}$ & 1,100 & 20 June \\
\hline 1987 & Mckenzie, N.D. & $\begin{array}{l}\text { malathion }{ }^{4} \\
\text { malathion }\end{array}$ & $\begin{array}{r}8,900 \\
15,000\end{array}$ & $\begin{array}{l}5 \text { July } \\
\text { S July }\end{array}$ \\
\hline 1987 & McKenzie, N.D. & N. locustats & $\begin{array}{l}13,0,700 \\
10,700\end{array}$ & 24 June \\
\hline 1988 & MeǨnzie, N.D. & carbaryl bail ${ }^{6}$ & 2,100 & 20 June \\
\hline 1989 & Shoshone, Ida. & malathion & 600 & 3 June \\
\hline 1989 & Bighorn. Wyo. & malathion & 2,900 & 13 June \\
\hline 1990 & Bïghorn. Wyo. & sevin-4-oil & 2.600 & 13 May \\
\hline 1990 & Bighorn. Wyo. & sevin-4-oll & 5.300 & 15 May \\
\hline 1990 & Shoshone, Ida. & malathion & 500 & 8 June \\
\hline 1990 & Mckenzie, N.D. & malathion & 1.700 & 3 July \\
\hline 1990 & MIcKenzie, N.D. & malathion & 3.100 & 8 July \\
\hline
\end{tabular}

Dute treatment applied, or if treatment was applied over seseral days, data that applica. tion was jinished.

$25 \%$ carharyl (wevin) wheat bran bait applied at $112 \mathrm{~kg} / \mathrm{ha}(10 \mathrm{lb} / \mathrm{ac})$.

*arbaryl (sevin) applied in oil formulution at $065 \mathrm{~g} / \mathrm{hat}(9.6 \mathrm{oz} / \mathrm{ac})$.

4 Maldthion applied at $0.65 \mathrm{hg} / \mathrm{ha}(9.6 \mathrm{oz} / \mathrm{ac}$ ) in an uftra low volume (ULV) formulation.

5 Nosima lontstac spores applied in wheat brats batt at $112 \mathrm{~kg} / \mathrm{ha}(1 \mathrm{lb} / \mathrm{ac})\left(2.47 \times 10^{9}\right.$ upore (hat).

62א carburyl (sevm) wheal bran bast applied at I $68 \mathrm{hg} / \mathrm{ha}(1.5 \mathrm{lbs} / \mathrm{ac})$.

data is warranted.

Bird densities were estimated using line transects (Emlen 1977) and point counts (Reynolds et al. 1980). At 12 locations we established, $4-11 \mathrm{~km}$ of line transects in both the treated and untreated areas. We used point counts $(n=20)$ on 1 treatment and untreated area in 1988 because rough terrain was unsuitable for use of line transects. Transects and points were $\geq 400 \mathrm{~m}$ apart. Complex juxtaposition of land ownership, land uses, and cover types precluded random location of transects on treated and untreated sites. Consequently, we selected large blocks $\left(>0.5 \mathrm{~km}^{2}\right)$ of contiguous habitat (mixedgrass prairie in North Dakota and sagesteppe vegetation elsewhere) and land use within treated and untreated areas for location of transects or points. We began transects $100 \mathrm{~m}$ from the nearest road and proceeded perpendicular to it.

Every $100 \mathrm{~m}$ markers were placed on the transect line and 10 and $25 \mathrm{~m}$ perpendicular to the line to aid in estimation of bird distances. We surveyed birds along transects 1 to 7 days before treatments and approximately 21 days posttreatment. Birds were surveyed along most of the transects approximately 2 and 10 days posttreatment.

We trained all field assistants in bird identification and distance estimation for 1-2 weeks before surveying. We assigned observers randomly to transects on treated and untreated areas to reduce observer bias. Birds were surveyed from approximately 15 min before sunrise $(\approx 0545$ hour) until 0930 -1030. During 1987-1989 each transect was surveyed independently by 2 observers on the same morning. In 1990, each transect was surveyed only once during a given period. The perpendicular distance from the transect line that each bird was seen or heard and the manner in which the bird was detected (singing, visual, calling, both visual and auditory, or flying over) were recorded as the observer slowly walked the transect $(\approx 2 \mathrm{~km} / \mathrm{h})$. Similar data were collected for $7 \mathrm{~min}$ at each stop on the point transects. We grouped detection distances into categories: $0-10 \mathrm{~m}, 11-25 \mathrm{~m}$, $26-50 \mathrm{~m}, 51-100 \mathrm{~m}, 101-150 \mathrm{~m}$, and $151-200 \mathrm{~m}$.

We computed a relative density index by computing a detection distance for each species (see Reynolds et al. 1980) and dividing the area sampled by the number of detections. Because pesticide applications may affect singing behavior (Grue and Shipley 1981), we computed relative densities for (1) all detections and (2) for detections of singing birds only. We recorded 38 species of grassland or shrubsteppe birds in sufficient numbers to estimate densities at $\geq 1$ area (Appendix 1). All of the species recorded at an area were used to calculate community measures (total density, and species richness, diversity, and evenness). We performed separate analyses on the 5 most abundant species: mourning doves (Zenaida macroura) horned larks (Eremophila alpestris), Brewer's sparrow (Spizella breweri), vesper sparrows (Pooecetes gramineus) and western meadowlarks (Sturnella neglecta). Other species occurred too infrequently for separate statistical analysis.

We computed total density by summing the densities of all of the species that were counted in an area. Species richness was the number of species detected along the transect. We computed species diversity as the inverse of Simpson's index, $N_{2}=$ $1 / \Sigma\left(p_{i}\right)^{2}$, where $p_{i}$ is the proportional density of species $i$. Evenness was calculated using the formula $E=N_{2} / N_{1}$, where $N_{1}$ $\left.=\exp -\sum \rho_{i} \ln \rho_{i}\right)$ as suggested by Hill (1973). We classified species that fed primarily on insects during the summer months as insectivores, species that relied on seeds, fruit, or vegetation for most their diet $(>50 \%)$ for some or all of this period were classified as noninsectivores. Diet was determined from analysis of crop, proventriculus, and gizzard contents of birds collected on or near the study areas or from the literature (Martin et al. 1951, Rotenberry and Wiens 1980). Guide classification for each species is listed in Appendix 1.

\section{Brain Acetylcholinesterase (AChE)}

We collected common bird species with shotguns on treated and untreated areas 1-21 days after treatment in North Dakota in 1987 and in Wyoming in 1989. At each location, we collected individuals of the same species on treated and untreated areas (>1 $\mathrm{km}$ from treated sites) on the same day. Most birds were immediately placed on solid $\mathrm{CO}_{2}$ in the field and were kept frozen until they were put in a laboratory deep freeze. Some specimens were placed on ice in the field and later frozen. Brain AChE activity was determined with procedures described by Ellman et al. (1961) as modified by Hill and Fleming (1982). We analyzed samples from treated and untreated sites alternately with the same equipment. The AChE values were expressed in $\mu \mathrm{mol} / \mathrm{min} / \mathrm{g}$ wet wt of brain tissue.

\section{Grasshopper Counts}

We estimated grasshopper densities by counts of grasshoppers flushed from $0.25 \mathrm{~m}^{2}$ hoops placed along the bird transects. Four hoops were placed at each of 10 points $(100 \mathrm{~m}$ apart) for a total of 40 hoops/transect. At each point, hoops were placed $5 \mathrm{~m}$ apart and $10 \mathrm{~m}$ to either side of the transect. We put out hoops the evening before the transects were surveyed and counted grasshoppers immediately after the bird surveys. Grasshopper densities were only estimated on the transects in North Dakota. Because there were no replicates of the carbaryl bait and $N$. locustae treatments in North Dakota, only data from malathion treatment areas were used in the analyses of the grasshopper densities. 


\section{Statistical Analyses}

The effects of treatment type (i.e. malathion, sevin-4-oil) on bird density and community measures (species richness, diversity, evenness, and guild density) were compared with repeated measures analysis of variance (ANOVA) (Milliken and Johnson 1984). Because bird densities differed greatly between sites, we used density ratio (treated/treated + untreated) rather than actual densities in the analyses (Eberhardt and Thomas 1991). Ratios were normalized with arcsine transformations for analysis. It has been suggested that bait applications may have less of an impact on nontarget wildlife than sprays (George et al. 1992), therefore, we tested for differences in density ratios among spray and bait applications between pre- and post-treatment surveys with linear contrasts (Dowdy and Wearden 1991). Because surveys were not conducted at several sites 2 and 10 days after treatment, including these periods in the analyses reduced sample sizes. Therefore, ANOVAs were computed for all data and for only the pre- and 21 day post-treatment ratios. Changes in bird density and community measures between pre- and post-treatment were tested with paired t-tests. We divided the level of significance $(\alpha=0.05)$ by the number of comparisons being made to control the experiment-wise error rate for multiple t-tests (Rice 1990). We computed the statistical power of detecting a 5\% difference between the treated and untreated sites for the bird community variables using the empirical variances and the actual sample sizes. We tested for effects of treatment area (ha) and date on bird abundance, using linear correlation. We used Pearson product moment correlations because the variables used in the analyses were normally distributed and there was no evidence of heteroscedasticity (Dowdy and Wearden 1991). The effects of treatment type and period on grasshopper densities were also tested with repeated measures ANOVA. We tested for differences in grasshopper densities between treated and untreated areas for each period with t-tests. All statistical tests were done with PC-SAS (SAS 1988).

Brain AChE of birds collected on treated and untreated sites were compared separately for each species and treatment area using a t-test. There was no difference $(P>0.2)$ in $\mathrm{AChE}$ levels from birds collected at different periods post-treatment so all post-treatment samples were combined for analysis. Brain AChE activity $>20 \%$ below or $>2$ sd below (whichever was lower) the mean of untreated birds was considered indicative of exposure to an AChE inhibiting chemical (Ludke et al. 1975). We determined the number of individuals in this category for each species-treatment combination.

\section{Results}

\section{Bird Densities}

The ratio of total density (treated/treated + untreated) differed among treatments for all birds $(\mathrm{F}=6.95, P=0.01)$ and for singing birds $(\mathrm{F}=5.13, P=0.02)$ for pre- and post-21 day surveys (Fig. 1); however, no period or period $\times$ treatment interactions were found. There also was no significant period $x$ bait vs spray interaction nor were there any differences among the linear contrasts between pre- and post-treatment surveys. Thus, there was no evidence of a change in the ratios among treatments between the pre- and post-treatment surveys. Density ratios did not differ among treatments on the pre-treatment surveys but the carbaryl bait treatment was higher $(P<0.05)$ than the other treatment types 21 days after treatment. Because there were no consistent differ-
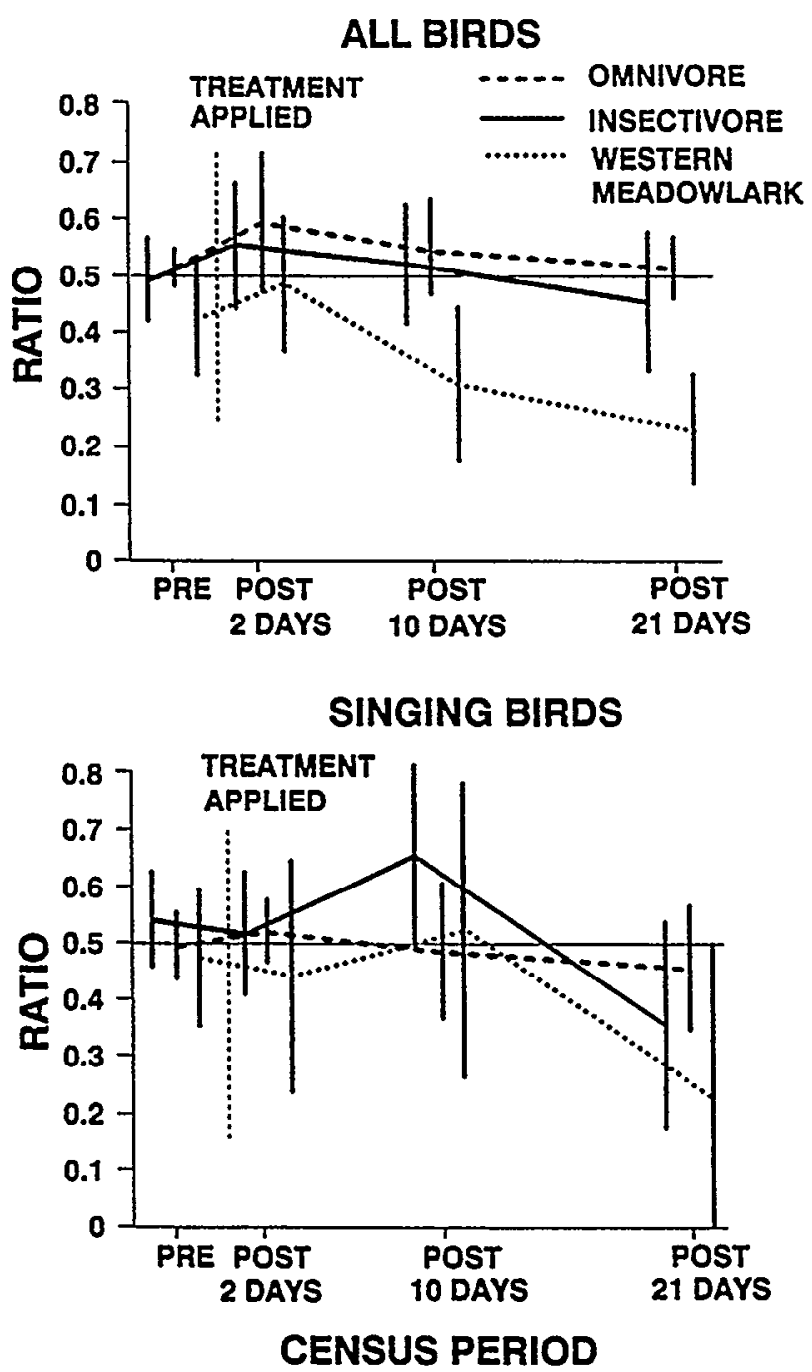

Fig. 1. Changes in density ratio (treated/treated + untreated) of total bird density on malathion, sevin-4-oil and carbaryl bait treatments pre- and post-treatment. Data were plotted separately for all birds detected, and for all singing birds. Vertical bars are 2 se, the horizontal line at 0.5 indicates equal numbers on treated and untreated areas.

ences in density ratios among the treatments and because the 2 treatments that were the most divergent had the smallest number of replicates, this difference likely resulted from a type I crror consequently we combined the data from all treatments for subsequent analyses. The results did not differ when these data were excluded from the analyses.

No differences in main effects of interaction terms were found for species richness or species diversity for either singing birds or all detections. The period $x$ treatment interaction was significant for species evenness for all detections $(F=9.7, P<0.004)$ but not for singing birds. The significant interaction term was due to an increase in evenness on the malathion treatment areas between pre- and post-21 day surveys $(P<0.01)$.

When treatments were combined, there were no differences between the pre- and post-treatment ratios for any of the bird community variables (Fig. 2). The results were similar when all birds or only singing birds were considered. The lack of significant differences was not due to low statistical power of the tests. 

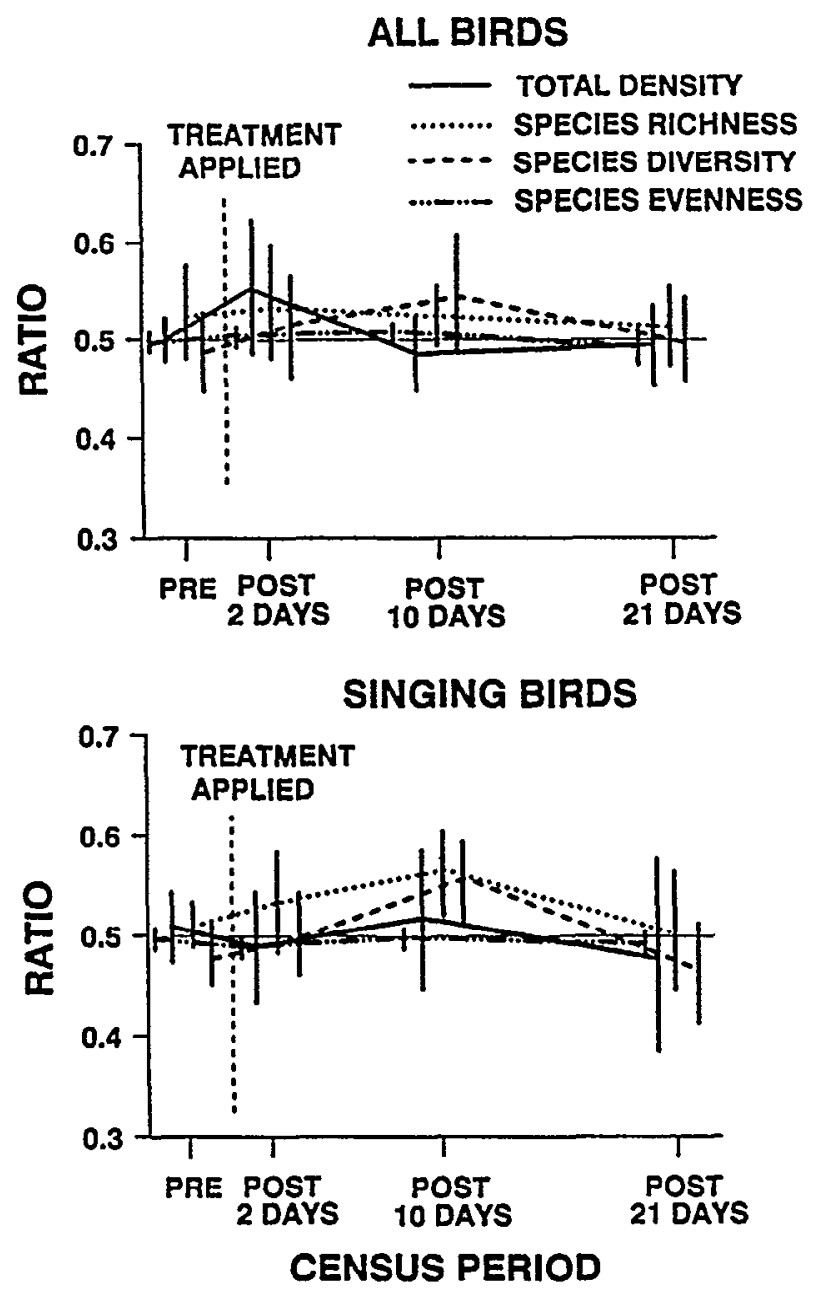

Fig. 2. Changes in ratio (treated/treated + untreated) of total density, species richness, species diversity, and species evenness pre- and post-treatment. Data were plotted separately for all birds detected, and singing birds. The vertical bars are 2 se, the horizontal line at 0.5 indicates equal numbers on treated and untreated areas.

The power of detecting a $5 \%$ difference between pre- and 21 day post-treatment ratios was greater than $98 \%$ for species diversity, richness, evenness, and total density for all detections.

There was no difference in the density of noninsectivores or insectivores between the pre- and post-treatment surveys. The density of western meadowlarks declined on the treated areas at 10 and 21 days post-treatment when all detections were considered $(P=0.005, N=8, t=3.46 ; P=0.02, N=13, t=2.29$, 1 tailed paired $t$-tests) (Fig. 3). No differences were found when only singing birds were considered. Sample sizes for singing birds were lower, however, which reduced the power of the tests. No differences were found for the other 4 species that we analyzed separately. Unlike the meadowlark, however, none of these species was recorded on all of the treatment sites and therefore the power of the tests for these species was reduced.

We found no relationship between bird density ratio 21 days post-treatment and the size of the areas treated for total bird density $(P>0.1)$. Because numbers of insectivores and western mead- owlarks were both lower 21 days post-treatment, we tested the same relationship for these groups. None of the correlations was significant $(P>0.1)$. We also found no relationship between treatment date and density ratio 21 days post-treatment for total bird, insectivore, or western meadowlark density $(P>0.1)$ for all comparisons).

\section{Brain Acetylcholinesterase}

Brain AChE levels of birds collected on treated and untreated areas did not differ significantly for any of the species-treatment comparisons $(P>0.1)$ (Table 2). One horned lark collected on a malathion treatment area showed evidence of $\mathrm{AChE}$ inhibition.

\section{Grasshopper Counts}

Grasshopper densities were depressed on the treated areas compared with the untreated sites in the post-treatments counts (Fig. 4). There was no treatment effect but there was a treatment $x$ period interaction $\left(F_{2,11}=4.49, P=0.038\right)$. Grasshopper densities were higher on the treatment areas before applications and were lower after.

\section{Discussion}

We found little evidence of differences in bird population response among all treatments or between bait and spray applications. Our sample of bait applications was small, however, and therefore we cannot make strong conclusions regarding their lack of impacts on bird populations. We postulate that integrated pest management bait treatments have less impact on nontarget wildlife because less chemical is applied, there is no dermal or inhalation exposure, and the animal and plant food is not coated with pesticides as with liquid sprays. Therefore baits would be preferable to sprays in environmentally sensitive situations.

Declines in bird density likely resulted from reduced food availability for insectivorous birds rather than direct toxic effects. No declines were found until 10 and 21 days after treatment. If declines were related to direct toxicity, effects likely would be observed within a few hours to a few days after treatment (Moulding 1976, Grue and Shipley 1981, Grue et al. 1983). Further, we found little evidence of depressed acetylcholinesterase activity in birds collected on the treatment areas and declines in grasshopper numbers on the treatment areas were consistent with indirect effects.

Grue and Shipley (1981) asserted that observations of declines in birds numbers on areas treated with organophosphate (OP) pesticides may be confounded by behavioral changes of birds exposed to pesticide. They found that activity and vocalization of male starlings (Sturnus vulgaris) declined 2-4 hours after the birds received oral doses of organ phosphates but returned to normal by $26-28$ hours after dosing. They suggested that these behavioral changes may reduce the detectability of birds that have been exposed at sub lethal levels. Avian surveys during that period could lead to the erroneous conclusion that bird numbers declined on treated areas. We feel it is unlikely our results were confounded by these kinds of behavioral changes. Bird numbers did not decline significantly until 10 and 21 days after treatment, which was well beyond the times noted by Grue and Shipley (1981). Secondly, there was little difference in results when all detections were used or only singing birds. 
Table 2. Summary of brain acetylcholinesterase (AChE) activity ( $\mu \mathrm{mol} / \mathrm{min} / \mathrm{g}$, wet wt) in birds collected on malathion treatment and nontreatment areas.

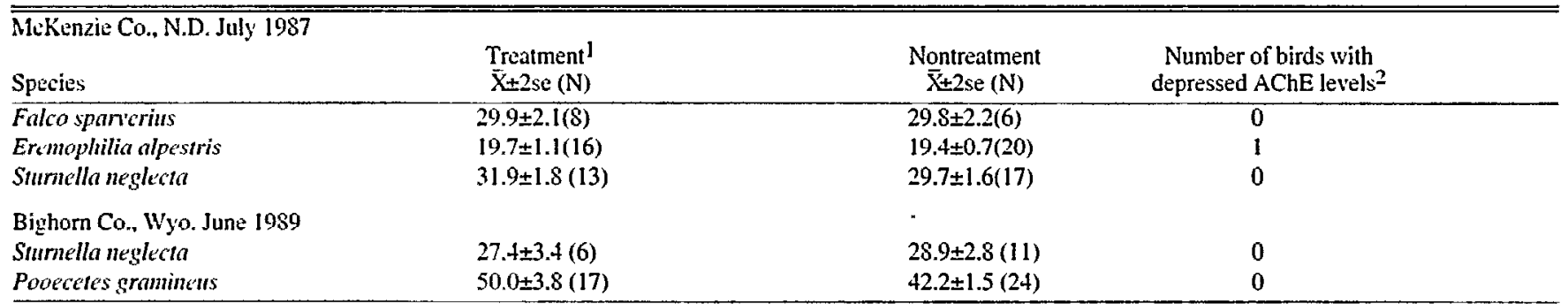

Miean AChE actwity of bird collected on treatment areas Birds were collected between I and 21 days post treatment.

2Burd w wh $\mathrm{AChE}$ acturity $=20 \%$ below or $>2$ id below (whichever was lower) the mean of untreated birds.

The decline in numbers of western meadowlarks on the treatment areas could be due either to increased mortality, decreased productivity, or emigration. When birds experience increased mortality or reduced productivity, the negative impact may affect the species of concern as well as predatory species such as the peregrine falcon (Falco peregrinus).

Most research on the effects of grasshopper treatments on nontarget wildlife has focused on direct effects. Investigations of the direct toxic effects of Ultra Low Volume malathion and carbaryl applications on nontarget wildlife populations in the field have generally shown little if any effect on common bird species (Hill et al. 1971, McEwen et al. 1972, DeWeese et al. 1979, Richmond et al. 1979, McEwen 1982, Stromborg et al. 1984, Kucera 1987, George et al. 1992). However, evidence is conflicting on the indirect impacts of carbaryl and malathion treatments on bird populations. McEwen et al. (1972) found no reduction in bird numbers between small (16-65 ha) replicated plots treated with malathion or carbaryl. George et al. (1992) also found no reduction in bird numbers on a large area (2.060 ha) treated with carbaryl bait. McEwen et al. (1972) and McEwen (1982), however, observed declines in bird numbers on some areas treated with carbaryl and malathion and suggested that birds may emigrate from treatment areas under some condition. Moulding (1976) observed a statistically significant decline in forest song bird densities over several weeks following 2 experimental treatments of carbaryl at 1.12 $\mathrm{kg} / \mathrm{ha}$. He interpreted the gradual decline as evidence of an indirect effect on the birds of reduced food supply but he did not compare brain acetylcholinesterase activity or food availability between the treated and untreated site after the spray. DeWeese et al. (1979) suggested that declines in numbers of ruby-crowned kinglets (Regulus calendula) after experimental treatments of trichlorfon and carbaryl on forests in Montana resulted from indirect effects. The data were not analyzed statistically, however, and therefore it is not clear if the observed declines were greater than expected by chance. Several others studies have shown no effect of ultra low volume, malathion or carbaryl applications on bird populations (Hill et al. 1971, James 1987, Richmond et al. 1979, McEwen and Ells 1975). These studies had few or no replicates, however, and therefore the ability to detect small treatment effects was low. Our results have shown that the effects may be rather subtle and limited to a subset of species within the community. It may be difficult, therefore, to detect treatment effects unless applications are sufficiently replicated or experiments are carefully designed.

Although we documented a significant decline in grasshopper density on the malathion treatment areas, it was difficult to deter- mine the impact that this may have on wild bird populations. Johnson and Boyce (1990) found that captive sage grouse (Centrocercus urophasianus) chicks $<21$ days old requires insects in the diet for survival and development, whereas older
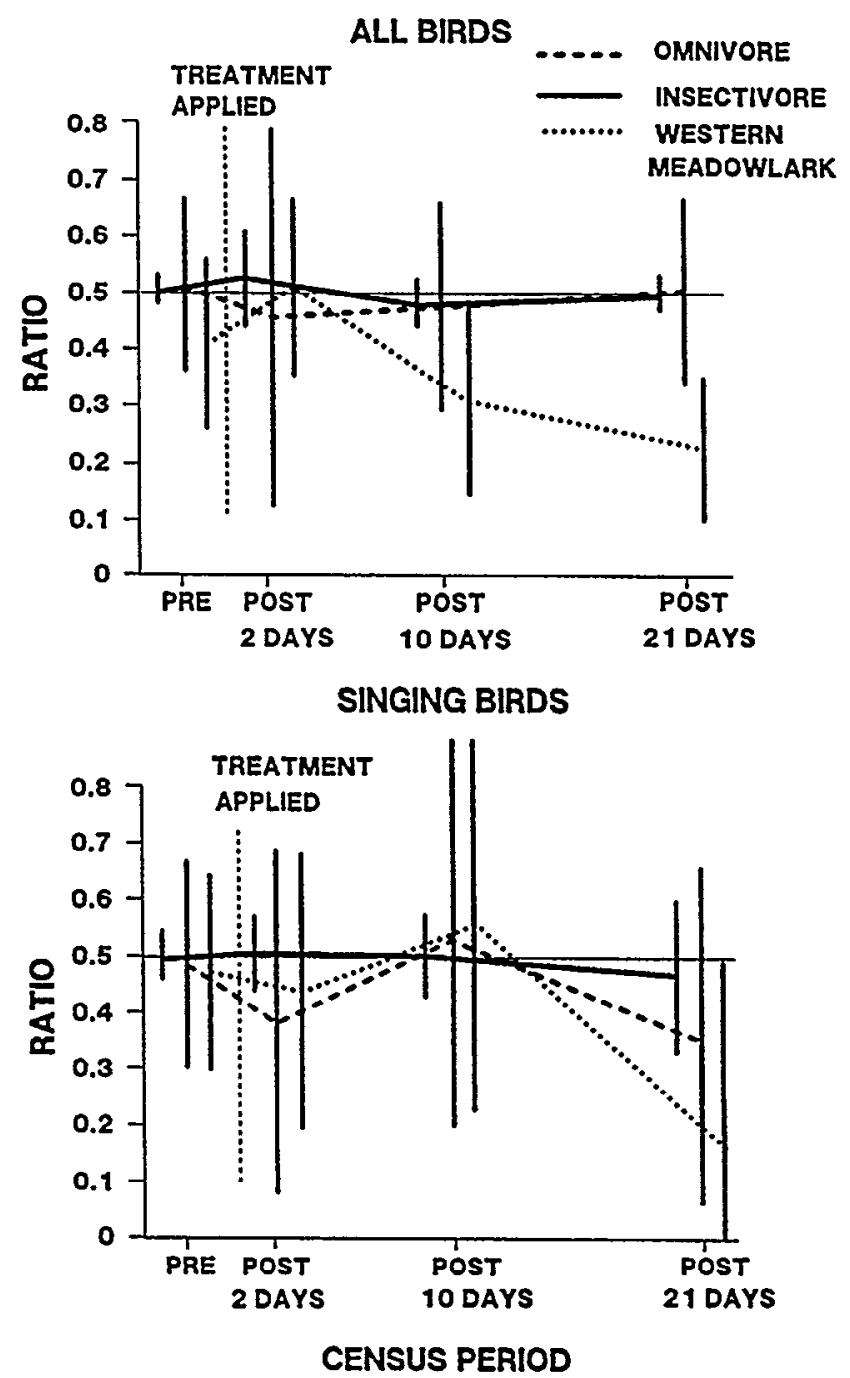

Fig. 3. Changes in density ratio (treated / treated + untreated) of insectivorous and noninsectivorous bird species, and western meadowlark densities pre- and post-treatment. Data were plotted separately for all birds detected, and singing birds. The vertical bars are $2 \mathrm{se}$, the horizontal line at 0.5 indicates equal numbers on treated and untreated areas. 


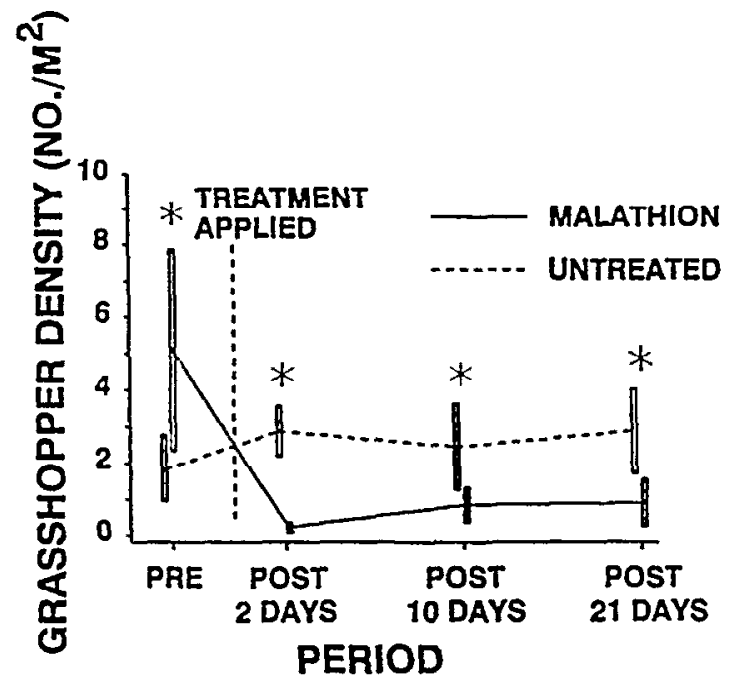

Fig. 4. Density of grasshoppers on malathion treatment and nontreatment sites in North Dakota. An asterisk indicates a significant difference between treatment and nontreatment sites for a particular period.

chicks needed insects to achieve maximum growth rates. These results suggested that sage grouse chicks and possibly other insectivorous birds may be sensitive to reductions in insect biomass. However, field studies have shown little effect of carbaryl or malathion applications on nestling growth and fledging success (James 1987, Adams et al. 1994, Howe 1993). More information is needed on the impacts of these treatments on the productivity of wild bird populations.

We failed to find a relationship between size of treatment area and changes in bird numbers on treatment sites although the trend was negative. None of our treatments exceeded 15.000 ha, therefore, we cannot make conclusions regarding impacts from larger spray programs. We also found no relationship between treatment date and changes in bird numbers. Several of the treatments were applied early in the breeding season when Johnson and Boyce (1990) suggested that the treatments may be most detrimental. We could not detect effects on productivity with the methods we used.

Birds have been shown to significantly reduce grasshopper densities in rangelands and may play an important role in maintaining grasshopper populations at endemic levels (Joern 1986, McEwen 1987, Fowler 1991, Bock et al. 1992). Pesticide applications that have adverse impacts on grasshopper predators may be counterproductive to long term integrated pest management goals. For this reason, it is important to incorporate birds and other grasshopper predators into any integrated pest management approach to grasshopper control.

\section{Literature Cited}

Adams, J., R.L. Knight, L.C. McEwen, and T.L. George. 1994. Survival and growth of nestling vesper sparrows exposed to experimental food reductions. Condor. 96:739-748.

Bock, C.E., J.H. Bock, and M.C. Grant. 1992. Effects of bird predation on grasshopper densities in an Arizona grassland. Ecol. 71:624-634.
Carpenter, S.R. 1990. Large scale perturbations: opportunities for innovation. Ecol. 71 :2038-2043.

Cook, T.D., and D.T. Campbell. 1979. Quasi-experimentation: design and analysis issues for field settings. Houghton Mifflin Co., Boston, Mass.

DeWeese, L.R. C.J. Henny, R.L. Floyd, K.A. Bobal, and A.W. Schultz. 1979. Response of breeding birds to aerial sprays of tirchlorfon (dylox) and carbaryl (sevin-4-oil) in Montana forest. U.S. Fish Wildl. Serv. Spec. Sci. Rep. - Wildl. No. 224. Washington, D.C. 29 pp.

Dowdy, S. and S. Wearden. 1991. Statistics for research. Wiley and Sons. New York. N.Y.

Ellman, G.L., K.D. Courtney, V. Andres, Jr., and R.M. Featherstone. 1961. A new and rapid colorimetric determination of acetylcholinesterase activity. Biochem. Pharmacol. 7:88-95.

Eberhardt L.L., and J.M. Thomas. 1991. Designing environmental field studies. Ecol. Monogr. 61:53-73.

Emlen, J.L. 1977. Estimating breeding season bird densities from transect counts. Auk. 94:455-468.

Fowler, A.C., T.L. George, R.L. Knight, and L.C. McEwen. 1991. The effect of bird predation on grasshopper populations (Orthoptera: Acrididae) in North Dakota Grassland. Ecol. 72:1775-1781.

George, T.L., L.C. McEwen, and A. Fowler. 1992. Effects of a carbaryl bait treatment on nontarget wildlife. Environ. Entomol. 21:12391247.

Grue, C.E., W.J. Fleming, D.G. Busby, and E.F. Hill. 1983. Assessing hazards of organophosphate pesticides to wildlife. Trans. North Amer. Wildl. Conf. 48:200-220.

Grue, C.E. and B.K. Shipley. 1981. Interpreting population estimates of birds following pesticide applications-behavior of male starlings exposed to an organophosphate pesticide. Studies Avian Biol. 6:292-296.

Hill, M.O. 1973. Diversity and evenness: a unifying notation and its consequences. Ecol. 54:427-432.

Hill, E.F., D.A. Elaison, and J.W. Kilpatrick. 1971. Effects of ultralow volume application of malathion in Hale County, Texas. III. Effects on nontarget animals. J. Med. Entomol. 8:173-179.

Hill, E.F., and W.J. Fleming. 1982. Anticholinesterase poisoning of birds: field monitoring and diagnosis of acute poisoning. Environ. Toxicol. Chem. 1:27-38.

Howe, F.P. 1993. Effects of an experimental food reduction on nesting shrubsteppe passerines. Ph.D. Diss.. Colorado State Univ., Fort Collins, Colo $108 \mathrm{pp}$.

James, P.C. 1987 Effects of some insecticides on productivity of burrowing owls. Blue Jay $45: 65-71$.

Joern, A. 1986. Experimental study of avian predation on coexisting grasshopper populations (Orthoptera: Acrididae) in a sandhills grasslands. Oikos 46:243-249.

Johnson, G.D., and M.S. Boyce. 1990. Feeding trials with insects in the diet of sage grouse chicks. J. Wildl. Manage. 54:89-91.

Kucera, E. 1987. Brain cholinesterase activity in birds after a city-wide aerial application of malathion. Bull. Environ. Contam. Toxicol. 38: $456-460$.

Ludke, J.L., E.F. Hill, and M.P. Dieter. 1975. Cholinesterase (ChE) response and related mortality among birds fed $\mathrm{ChE}$ inhibitors. Arch. Environ. Contam. 3:1-21.

Martin, A.C., H.S. Zim, and A. L. Nelson. 1951. American wildlife and plants. McGraw-Hill Book Company, Inc. N.Y. 500 pp.

McEwen, L.C. 1982. Review of grasshopper pesticides vs. rangeland wildlife and habitat. pp. 362-382. $\mathrm{m}$ : Peek, J.M. and P.D. Dalke, (eds.), Proc. Wildl.-Livestock Relationships Symp., Forest. Wildl. Range Expt. Station, Moscow, Ida.

McEwen, L.C. 1987. Function of insectivorous birds in a shortgrass IPM system. In: J.L. Capinera, (ed.), Integrated pest management on rangelands: a shortgrass prairie perspective. Westview Press, Boulder.

McEwen, L.C., and J.O. Ells. 1975. Field ecology investigations of the effects of selected pesticides on wildlife populations. U.S. Intern. Biol. Prog. Tech. Rep. 289. Colorado State Univ.. Fort Collins. Colo. 54 pp.

McEwen, L.C., C.E. Knittle, and M.L. Richmond. 1972. Wildlife effects from grasshopper insecticides sprayed on short-grass prairie. $J$. Range Manage. 25:188-194. 
Milliken, G.A. and D.E. Johnson. 1984. Analysis of messy data. Vol. 1 Van Nostrand Reinhold. New York. N.Y.

Moulding, J.D. 1976. Effects of a low-persistence insecticide on forest bird populations. Auk. 93:692-708.

Reynolds, R.T., J.M. Scott, and R.A. Nussbaum. 1980. A variable circular-plot method for estimating bird numbers. Condor 82:309-313.

Rice, W.R. 1990. A concensus combined $P$-value test and the familywide significance of component tests. Biometrics 46:303-308.

Richmond, M.L., C.J. Henney, R.L. Floyd, R.W. Mannan, D.M. Finch, and L.R. DeWeese. 1979. Effects of sevin-4-oil, dimilin, and orthene on forest birds in northeastern Oregon. Pac. Southwest Forest Range Exp. Sta. Res. Paper PSW-148. 19pp.
Rotenberry, J.T., and J.A. Wiens. 1980. Dietary relationships among shrubsteppe birds: competition or opportunism in a variable environment? Ecol. Monogr. 50:93-110.

SAS Institute Inc. 1988. SAS/STAT User's Guide, Release 6.03 Edition. Cary, N.C.: SAS Institute, Inc. 1028 p.

Stromborg, K.L., L.C. McEwen, and T. Lamont. 1984. Organophosphate residues in grasshoppers from sprayed rangelands. Chem. Ecol. $2: 39-45$.

USDA-APHIS 1987. Final environmental impact statement on the rangeland cooperative management program APHIS FEIS 87-1. Hyattsville, Md.

Appendix 1. List of bird species used in density analyses. Classification into feeding guild was based on diet information from Martin et al. 1951 and from analyses of stomach (crop and proventriculus) contents of birds collected on or near treatment sites.

\begin{tabular}{|c|c|c|c|c|c|}
\hline Common name & Scientific name & Dietary guild! & Common name & Scientific name & Dietary guild ${ }^{\prime}$ \\
\hline American kestrel & Falco spanveritus & I & American robin & Turdus migratorius & I \\
\hline chukar & Alectoris chukar & I & sage thrasher & Oreoscoptes montanus & I \\
\hline sage grouse & Centracercus urophasianus & I & Sprague's pipit & Amthus spragueii & I \\
\hline sharp-tailed grouse & Tympanuchus plutsianellus & I & loggerhead shrike & Lanius ludovicianus & I \\
\hline killdeer & Charadrius vociferus & 1 & common yellowthroat & Geothlypis trichas & I \\
\hline upland sandpiper & Bartramia longicuada & I & green-tailed towhee & Pipilo chlorturus & I \\
\hline long-billed curlew & Numenius mericanus & I & chipping sparrow & Spizella passerina & I \\
\hline mourning dove & Zenaida macrotira & $\mathrm{N}$ & clay-colored sparrow & Spizella pallida & 1 \\
\hline common nighthawk & Chordelles minor & I & Brewer's spartow & Spizella breweri & I \\
\hline gray flycatcher & Empidonax wrigltii & I & field sparrow & Spizella pusilla & 1 \\
\hline Say's phoebe & Sayornis saya & I & vesper sparrow & Pooccetes gramineus & $I$ \\
\hline Western kingbird & Tyranmus vertucalis & I & lark sparrow & Chondestes grammacus & I \\
\hline Eastem kingbird & Tyramms tyramms & I & sage sparrow & Amphispiza belli & I \\
\hline horned lark & Eremophila alpestris & $N$ & lark bunting & Calamospiza melanocons & I \\
\hline black-billed magpie & Pica pica & I & Baird's spamrow & Ammodramus bairdii & I \\
\hline American crow & Conus brachyrhynchos & I & grasshopper sparrow & Ammadramus savannarum & I \\
\hline rock wren & Salpinctes obsolenus & I & Western meadowlark & Stumella neglecta & I \\
\hline westem bluebird & Sialia mexicana & I & Brewer's blackbird & Euphagus cyanocephalus & I \\
\hline mountain bluebird & Sialia currucoides & I & Brown-headed Cowbird & Molothrts ater & $\mathrm{N}$ \\
\hline
\end{tabular}

'Dietary guild was classified as follows. I- Insectiv ore, $>50 \%$ of the diet is composed of arthropods during the summer months. $N$ - Noninsectrore, $<50 \%$ of the diet is composed of arthropods during the summer months. 